\title{
Teachers Use of Tools for Student Success: Challenging Learning Behaviors
}

\author{
Dr. Francie R. Murry \\ University of Northern Colorado
}

\begin{abstract}
This study investigated the impact teacher's use of two tools on the social and academic behaviors of twenty middle school students. The general education teachers described the students as assignment incompleters but bright enough to complete work. These students were at risk for failing the majority of their classes in the first semester and were being considered for interventions at the third tier of the Response to Intervention (RTI) model. Four research questions were identified to explore the use of the 9-Grid tool for teachers' use in the identification of needed assignment adaptations and the RAFT to implement the assignment differentiation. Both tools were used in the content areas of music, mathematics, history, science, and physical education over a 6week period. Results indicated that students increased in both social and academic behaviors after teachers implemented their use of the 9-Grid and the RAFT.
\end{abstract}

Behavior challenges displayed by students are associated with negative consequences for academic success and engagement in school (Arcia, 2006; Butler, Bond, Drew, Krelle, \& Seal, 2005; Levendoski \& Cartledge, 2000; O’Shaughnessy, Lane, Gresham, \& Beebe-Frankenberger, 2002), whether caused by a lack of skills, organic origins, or cognitive errors. Countries differ in how they approach student behavior; with variations in policies that legally mandate support and positive interventions to school suspensions. In the United States legislation has been passed in an attempt to address this dual problem of social and academic student issues. Legal acts in the United States for both general and special education require that teachers focus on student social and academic behaviors to provide effective instruction for all students (Skiba \& Rausch, 2006).

\section{Response to Intervention for General Education}

When the concept of Response to Intervention (RTI) was included in the Every Student Succeeds Act (ESSA) in 2015; it was to provide problem-solving service delivery for all students including those with behavior difficulties (National Center on Response to Intervention, 2010). As of the 2017-18 school year, the ESSA is in full effect. It requires that schools develop multi-tiered systems of support that include evidence-based AND systemic practices to respond to students' needs. RTI is dependent on teacher knowledge, skills, and ability to use data-based instructional decision-making, and deliver effective educational interventions for groups, as well as, individual students (DeWitt, 2016). Delivering evidencebased interventions with integrity and frequent monitoring of the RTI tiered interventions provide an invaluable database for teachers to detect the need to change or sustain a particular intervention (Vellutino, Scanlon, Small, \& Fanuele, 2006).

\section{Response to Intervention for Special Education}

RTI is included in the special education act known as the Individuals with Disabilities Education Act 2004 (IDEA 2004). It too promotes a system of tiered supports to deliver effective interventions for students being evaluated for needing special education services (National Center for Learning Disabilities, 2018). When students with challenging behaviors 
are engaged in and able to function within the classroom, misbehavior is typically less likely to occur (Kauffman, 2010; Witt, VanDerHeyden, \& Gibertson, 2004). Many of these students also have learning problems or skill gaps that keep them from being able to participate effectively in grade level assignments (Sabornie, Cullinan, Osborne, \& Brock, 2005). Their disabilities identified across the content areas (Reid, Gonzalez, Nordness, Trout, \& Epstein, 2004) also include a range with gaps in academic skills, often leave teachers at a loss as to how to support them. The interventions in RTI must have research to back their use, so teachers can replicate them with confidence and sustain the flow of instruction and learning.

Identifying techniques that engage students who are struggling while creating ways for them to access content is a challenge for both teachers and students. When teachers present material using approaches that support student's competence, students can be coaxed to engage in more sophisticated deliveries. It is beneficial to have students begin work in their areas of strength, bypassing the discouragement often outwardly displayed when they are presented with an unfamiliar or challenging assignment. Teachers need ways of allowing students to work within their strengths and integrate the weaker areas into the assignment to provide a vehicle through which to teach needed skills. Connecting subject area assignments to student interests and/or authentic life activities supports teachers' abilities to require lesson plan objectives and meet the content standards attainment. Performances and work products must be collected and assessed against the content standards to identify what students know and what they need to learn. Once teachers understand what students are capable of, they can ask students to demonstrate their learning using formats that both draw upon their interests and meet their needs.

This study was conducted to investigate the use of two evidence-based tools, the RAFT, and the 9-Grid. The RAFT was used as a tertiary technique to strengthen deficits that students displayed as challenging academic behaviors. A secondary tool, the 9-Grid, was used to strengthen teachers' understanding of differentiation and potential use of adaptations while developing the RAFTs (DeSchenes, Ebeling, \& Sprague, 1994).

\section{TECHNIQUE ONE: THE RAFT}

The RAFT, first introduced by Holston and Santa in 1985, was used to enhance written assignments. It is a very versatile tool because differentiated instruction and the ability to meet content standards for all content areas can be embedded within the format. The commonly accepted description of the RAFT is it is a tool that allows "students to demonstrate their understanding of a topic or submit through a writing experience that helps them to think and communicate their understanding of it in a creative and interesting way, encourages students to organize their thoughts, and keeps the students' attention" (Parilasanti, 2014, p. 2).

\section{RAFT Components}

The role that students decide upon will differ from the traditional role of being a student reporter of information provided to the teacher in order to demonstrate their learning about a topic. The student(s) demonstrate application and exploration of the specified topic aligned with content standards. The assignment components are identified through the use of the acronym RAFT. Students are guided to identify the Role (R) from which they disseminate the information learned, the Audience (A) to whom they are giving the information output, through a specified Format (F) of their work on the expected content Topic (T). Even though the RAFT concept is to deviate from the traditionally written report of information, traditional option format can be included as a row on the RAFT. 
The RAFT will have students demonstrate learning about a topic by presenting information to a hypothetical audience in varying delivery formats. For instance, the student is in a mathematics class studying line segments and parallel lines and take the Role of "A Line." $\mathrm{He} / \mathrm{she}$ communicates to "Other Lines" (Audience) through a "Full Page Personal Ad" (Format) concerning "Being Parallel with One Another" (Topic). See the example row on the RAFT in Figure 1. Communication in mathematics should involve talking, reading, and/or writing (Freitag, 1997; Schinck-Mikel \& Pugalee, 2014). Talking with others about mathematical concepts and ideas not only broadens the students' ability to articulate their understanding but, also allows them to explore multiple perspectives.

Figure 1: Example of one row on a RAFT. This figure illustrates the components on a RAFT row used for mathematics.

\begin{tabular}{|c|l|c|c|}
\hline Role & \multicolumn{1}{|c|}{ Audience } & Format & Topic \\
\hline Straight Line & Other Lines & Full Page Personal Ad & Can We Be Parallel? \\
\hline
\end{tabular}

\section{RAFT Flexibility}

The RAFT replaces the traditional report format with opportunities to demonstrate knowledge with more flexibility. This flexibility allows students with challenging behaviors and academic deficits greater opportunities to be engaged in what they may perceive as an instructional challenge. If students find the flexibility in the RAFT format relieves the stress of performance, the technique is less likely to exacerbate misbehaviors. RAFTs provide teachers with a systematic way to differentiate assignments within the content they teach, how students get information, and how they will demonstrate the knowledge they have gained. Student preference for demonstrating knowledge (e.g., output) can be tailored to their specific needs. For instance, in the same mathematics class, the teacher can create a RAFT row for a student who has specific learning needs based on characteristics commonly attributed to comorbidity students who are Gifted/Talented and also have Attention Deficit Hyperactivity Disorder. For this student's need, the RAFT allows for more in-depth investigation of the topic and greater allowance for movement and drawing. See the example row on a RAFT in Figure 2. The Role, in this case, is The Chief in Clash of Clans, addressing the Audience of clan members, using the Format of creating a graphic of walls and defining strategies to explain the Topic question of "Graphic Inequalities: Will They Help Us Build a Defensible and Prosperous Village?"

Figure 2. Example RAFT in History for a Student with Comorbidity Learning Characteristics

\begin{tabular}{|l|l|l|l|}
\hline \multicolumn{1}{|c|}{ Role } & \multicolumn{1}{c|}{ Audience } & \multicolumn{1}{c|}{ Format } & \multicolumn{1}{c|}{ Topic } \\
\hline $\begin{array}{l}\text { The Chief in Clash of } \\
\text { Clans }\end{array}$ & Clan Members & $\begin{array}{l}\text { Creation of Graphic } \\
\text { Walls and Definition } \\
\text { of Strategy use }\end{array}$ & $\begin{array}{l}\text { Graphic Inequalities: } \\
\text { Will They Help Us } \\
\text { Build a Defensible and } \\
\text { Prosperous Village? }\end{array}$ \\
\hline
\end{tabular}

Grant and Gladwell (2010) used the RAFT as a motivational tool by directing students to become a fictional figure. This imaginary enabled the students to address big ideas and meet literacy core content standards. Lenski and Lewis (2008) provided social validity for the use of the RAFT by reporting that adolescents enjoyed the format and teachers believed students benefited when the RAFT technique was used as a method of writing across the content areas. Having another way of approaching teaching and thinking about how learning occurs helps teachers identify the differences in diverse groups and provides a framework for assignment differentiation (Tomlinson, 2014). The differentiation tool needs to be easy to use, have multiple applications, useful across the various tasks expected of students, and add a bonus to the process. The specific bonus of the RAFT tool is that it provides enjoyment for both teacher and student. Students who appear unmotivated to attempt or complete an assigned task may 
actually be hiding their reactions to stress-associated tasks. When teachers personalize learning they can alleviate stress caused by social and academic difficulties (Sprenger, 2008). The RAFT tool can support needed personalization during teacher lesson development. As teachers prepare lessons, they must consider the various ways students learn and in doing so recognize learning as a highly personal process, which is individualized for absorbing and retaining information (Williamson \& Watson, 2006).

\section{Creating a RAFT}

The RAFT development requires that the teacher use their understanding and have knowledge of the levels at which their students are functioning, interests their students have, and students' preferences for demonstrating knowledge. The teacher aligns the topical concepts with the content standards that they want as outcome knowledge. The RAFT, as a whole or each row, can be matched with specific content standards. See the RAFT example of how the Format column is aligned with Colorado Content Standard 4 for sixth grade students in Figure 3. The Content Standard 4 for Reading, Writing and Communicating sixth grade level expectations is titled Research and Reasoning. This standard has three major components that the students will achieve. They are 1) Individual and group research projects require obtaining information on a topic from a variety of sources and organizing it for presentation; 2) Assumptions can be concealed, and require identification and evaluation; and 3) Monitoring the thinking of self and others is a disciplined way to maintain awareness.

Often students may not show interest in a subject or find a topic too challenging to begin the assigned task. They may have difficulty with the way in which the assignment (e.g., output) is expected to be completed. Barriers such as these can be alleviated through the design of a RAFT by combining content areas, so that one is of the student's interest.

\section{Thematic RAFT Design}

RAFTs can be designed to promote thematic teaching across content areas, expand traditionally-based student output, and combine strong student interests with weaker content interests. For instance, a RAFT can incorporate movement, literacy, and mathematical components to address several content standards (i.e., thematic use), and include at least one specific topic area which may be more appealing to a student's interest than another. History instruction is strengthened when areas such as reasoning, problem-solving, and communication are combined. The interactions with others also support the enhancement of teacher-guided social interactions that may not otherwise occur among students. The RAFT may be developed to capitalize on a student's high potential for communication while simultaneously incorporating historical concepts that they may otherwise not see as viable due to previous or current writing or reading difficulty. While the RAFT in Figure 3 addresses standard evidence outcomes, each of the rows demonstrate how the integration of literacy and history content can be used for effective differentiation. 
Figure 3. Example of Thematic RAFT for English and History.

\begin{tabular}{|l|l|l|l|}
\hline \multicolumn{1}{|c|}{ Role } & \multicolumn{1}{c|}{ Audience } & \multicolumn{1}{c|}{ Format } & \multicolumn{1}{c|}{ Topic } \\
\hline $\begin{array}{l}\text { Union (or } \\
\text { Confederate) Solider }\end{array}$ & $\begin{array}{l}\text { People in Public } \\
\text { Square }\end{array}$ & Public Speech & $\begin{array}{l}\text { I Must Fight for the Union (or } \\
\text { Confederacy) -Don't You See } \\
\text { Why it is Important? }\end{array}$ \\
\hline $\begin{array}{l}\text { Adolescent female (or } \\
\text { male) who is still at } \\
\text { home }\end{array}$ & Father & $\begin{array}{l}\text { Persuasive } \\
\text { Letter }\end{array}$ & $\begin{array}{l}\text { Dad, I Support the Union Oor } \\
\text { Confederacy). The War Has } \\
\text { Affected my Potential Future. }\end{array}$ \\
\hline $\begin{array}{l}\text { Common Woman on } \\
\text { Union side }\end{array}$ & $\begin{array}{l}\text { Confederate } \\
\text { soldier }\end{array}$ & Informal letter & $\begin{array}{l}\text { Do You Know How or Can You } \\
\text { Care About the Impact on my } \\
\text { Family if my Husband is } \\
\text { Wounded or Killed? }\end{array}$ \\
\hline $\begin{array}{l}\text { Well-Known Public } \\
\text { Figure of the time } \\
\text { (you select) }\end{array}$ & Readers & $\begin{array}{l}\text { Newspaper } \\
\text { Editorial }\end{array}$ & $\begin{array}{l}\text { My Side is the Correct One. (?) } \\
\text { Reasons You Need to Join Me! }\end{array}$ \\
\hline
\end{tabular}

\section{SECOND TECHNIQUE: 9-GRID}

The 9-Grid supports teacher identification of adaptations individual students or groups of students can use to access content area information and demonstrate learning. The 9-Grid was introduced as an adaptive tool by DeSchenes, Ebeling, and Sprague (1994). They identified nine types of environmental, instructional or material adaptations. They suggested that seven be targeted as essential for students with learning disabilities (i.e., size, time, level of support, input, difficulty, output, and participation). If significant adaptations such as difficultly or output of assigned task are made so the student can meet the content standard, then a modification in the grading scale may also need to be considered. The two additional types of adaptations that DeSchenes et al. included were alternative goals and substitute curriculum considerations for students with severe needs. In this study, the teachers did not address these two areas for intellectual adaptations. See the example of a completed 9-Grid for a student in a mathematics class who experienced high anxiety, preference for the verbal modality of expression, difficulty with fine motor skills in handwriting, and a deficit in the speed of processing information (Figure 4). 
Figure 4. Nine-Grid Example Completed for Mica by Mathematics Teacher

\begin{tabular}{|c|}
\hline Quantity/Size \\
Mica has \\
processing deficit - \\
reduce number of \\
problems - only \\
complete every $\mathrm{n}^{\text {th }}$ \\
problem for in-class or
\end{tabular}

\begin{tabular}{|c|}
\hline Time \\
May ask for extra \\
time up to one day on \\
homework when \\
necessary due to \\
anxiety.
\end{tabular}

Level of Support

Provide peer buddy caution Mica is talkative - so ensure on-task buddy is selected.

Will meet me after class or during school for
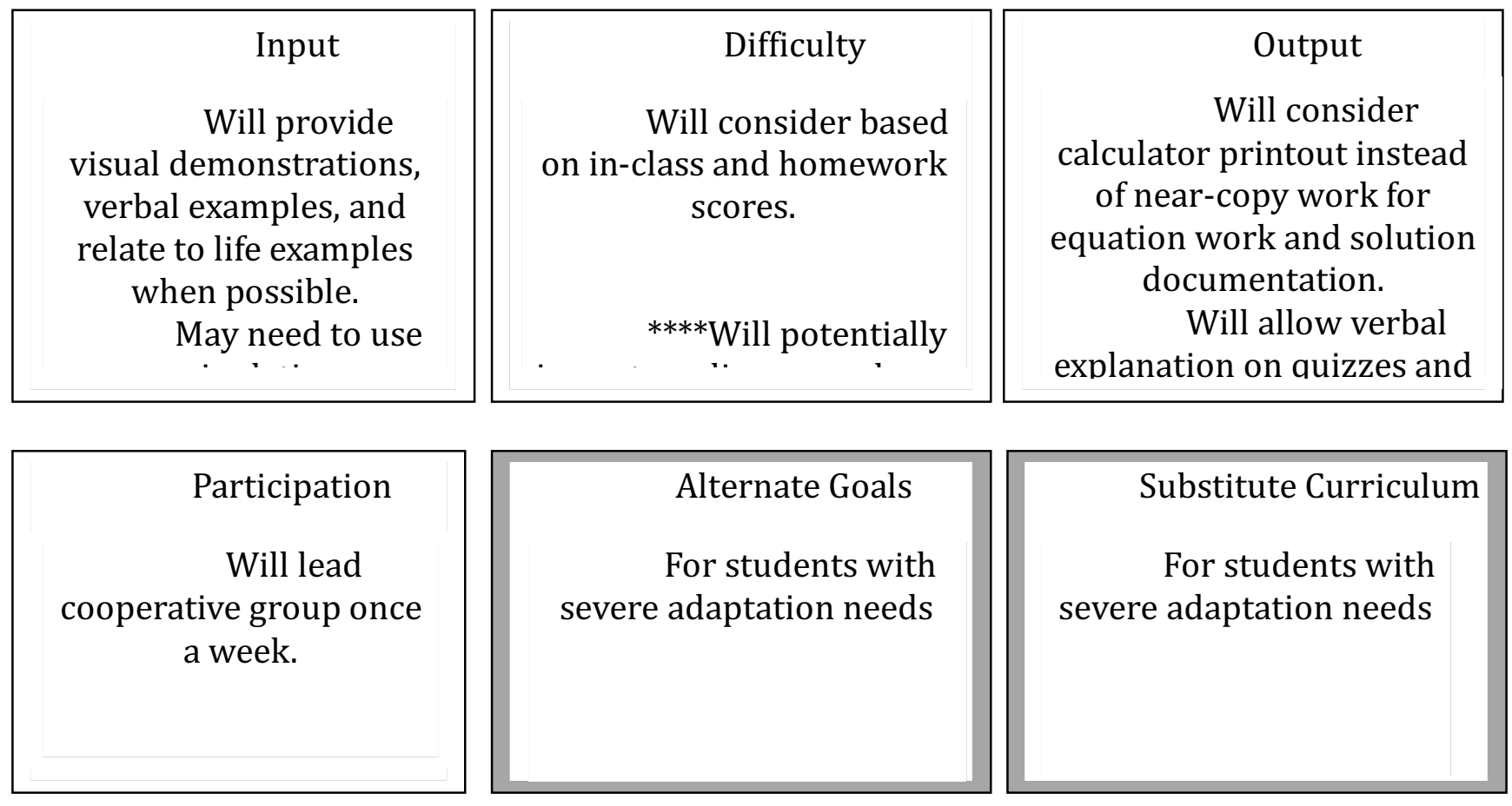

DeSchenes, Ebeling, \& Sprague (1994).

Size or Quantity adaptations include considerations such as the number of items that a student was expected to learn or complete. Size adaptations should provide students with more opportunities to complete assignments and a greater chance to earn reinforcement. For instance, a worksheet could be divided into multiple "strips" to be completed throughout a class period, or a lesson could be divided into multiple mini-lessons (Price, 2014).

Time adaptations should increase student responses and engagement with the lesson. Time extension is the most common adaptation provided for task completion. However, it may run contraindicative to achieving student engagement in the lesson and active responses during instructional periods (Heward, 1994). Extension length and when to award extra time should be carefully considered to promote assignment completion, rather than the student thinking they had permission to "check-out."

Adaptations using Levels of Support vary. They may include social, personal, material, technology, or physical assistance (Johns, 2015). Level of support can provide models for observational learning and clarify behavioral and academic expectations. Examples include peer-tutors, cooperative learning groups, graphic organizers, guided notes, visual schedules, study carrels, teacher-student meetings, and assigned seating. 
Input adaptations are teacher-dependent as they are the way the instruction is delivered to the student. Input can include computer-assisted instruction, other types of media, audio, didactic instruction or direct instruction. Input supports the focus of instruction and can guide the rate and level at which information is disseminated.

Adaptations for Difficulty are often made to the skill level of the student. In order to do this adaptation well so as not to change the content standard, teachers must have a clear understanding of the type of problems for which they are making adaptations. Teachers will want to adapt to students' need rather than exchanging content standard fulfillment. Adaptations to support difficulty levels may include voice recordings or visual/graphic formats rather than written forms of output for end-products or recorded lectures with guided notes to avoid input difficulty.

Output is how students respond to the input provided. The demonstration of knowledge can be completed in a variety of ways. Some examples may include the traditional written report, however, many other routes for students to show their learning outcomes are available. With technology so readily available, there are a variety of avenues for students to demonstrate learning from blogging, video modeling of a skill, emailing an author, or a collage of photographs depicting a timeline or event. Output allows students to validate learning while being guided by the teacher to attempt more difficult or less attractive output mediums.

Using Participation adaptations during class discussions or lectures provides a vehicle that should enhance student engagement, ability to respond, and increase responses. Teachers may use response cards or computerized class response systems to ensure response opportunity for all students. Participation and output adaptations may overlap or be similar because they both serve to provide access and an increase of opportunities for the student engagement and demonstrate their knowledge. Both also require the teacher to acknowledge and address individual student needs and differences for instructional approaches and formats (i.e., output).

\section{Participants}

\section{METHOD}

After completing a course which included the introduction to and practiced use of the 9-Grid and the RAFT, five $6^{\text {th }}$ grade teachers agreed to complete the 9-Grid for their class as a whole and individually for 20 identified students. The five teachers taught in the content areas of physical education, music, history, science, and mathematics and used the 9-Grid and the RAFT for the last six weeks of the remaining grade period. The teachers collectively shared 20 students considered for referral to a Tier 3 Response to Intervention plan due to failing grades. The teachers described the 20 students as "assignment incompleters, but seemingly intelligent enough to do the work assigned." The teachers hypothesized that both the students' social and academic misbehaviors were used to avoid assignments they perceived as dull and/or difficult.

\section{Research Questions}

The teachers examined their use of the 9-grid (DeSchenes, Ebeling, \& Sprague, 1994) to align adaptation needs with specific RAFT assignment differentiation for the students. Based on initial conversations with each of the teachers, four research questions were composed.

1. Would students' positive social and academic work completion behaviors increase if they had more choice in how they demonstrated what they learned?

2. Would students' positive social and academic work completion behaviors increase if the teachers used a variation of input? 
3. Would students' social and academic misbehaviors decrease if the teachers used instructional methods that allowed more student choice, interaction, and/or physical movement than they currently allowed?

4. Would students' social and academic misbehaviors decrease if assignments integrated items of interest to their daily lives?

\section{Instruments}

Interest survey: Each student completed an interest survey. The survey identified students' hobbies, favorite outings, school subjects, sports, foods, books, movies, likes/dislikes, best selfidentified learning modalities, talents, and skills. This information was used to identify the various ways teachers could connect their content areas lesson formats and how students could demonstrate learning from lesson information.

Social Competence Scale for Teenagers: This scale (Child Trends, 2003) has been tested with a nationally representative sample of teenagers aged 12-17. The scale consists of 9 questions that have a scale score from 0 to 4 (i.e., Not at all like $m e=0$, A little like me $=1$, Somewhat like $\mathrm{me}=2$; A lot like=3; and Exactly like me=4). The maximum score for this scale equals 36. Total scores allow for quick overviews of how students are doing, as well as a comparison in aggregate use on pre/post testing. It has been found to have excellent reliability (alpha=.79) and concurrent validity (associated with better grades and a lower likelihood of smoking, fighting, and depressive symptoms).

RAFT: The teacher identified areas that each student needed support to provide tailored differentiation before the RAFT (Holston \& Santa, 1985) technique was used. The RAFT used for this study was adapted from this original work.

9-Grid: A tool titled, the 9-Grid (DeSchenes, Ebeling, \& Sprague, 1994) identified student needs by considering adaptations in nine areas, of which seven were targeted as essential for students with learning disabilities (i.e., quantity, time, level of support, input, difficulty, output, and participation). The two additional areas were for students with severe needs (i.e., alternative goals and substitute curriculum) and were not considered for use in this study.

\section{Procedures}

Applying the student interest survey results, teachers completed the first seven areas of the 9Grid to identify the most beneficial and/or effective adaptations for individual students. The teachers completed the 9-Grid on each student and then shared with one another. As a group, they brainstormed across their content areas encouraging ideas for thematic content use. After identifying student need, each teacher aligned the next 6 weeks of assignments with the students' adaptive needs as identified on the 9-Grid. Keeping the 9-Grid findings and the student interest survey results in mind, the teachers created RAFTs for assignments where the adaptive differentiation could be used. For the next 6 weeks, teachers used RAFTs to motivate, engage, and teach students in their content classes. They kept track of their interaction with other students during group work, how many assignments they completed, and with what level of accuracy.

\section{Teacher Qualitative Reports}

\section{RESULTS}

Teachers reported that the most difficult aspect of the study was to find the time when five teachers could meet at once for an extended amount of time. They all found the brainstorming session valuable to discuss ideas for adaptations and for developing thematic assignments across content areas. 


\section{Teacher 9-Grid Development}

The teachers reported that completing the 9-Grid was initially difficult because they realized they did not know some of the students' needs; they only saw the outward display of challenging behaviors that they found to be disruptive to the teaching and learning process. As they examined the seven areas for the need of adaptation, they reported a more confident ability to add supports to the lessons they developed. They also reported that as they completed the 9-Grid for these students, they saw how the same adaptations could be used for many students in their classes.

\section{Teacher RAFT Implementation}

The teachers created RAFTs as outlined by Holston and Santa (1985) for assignments that they perceived needed to be differentiated based on student identified needs and strengths. Each RAFT followed the sequence of the acronym format. The letter R identified the Role from which the student delivered information, the A identified the Audience to whom the student was addressing, $\mathrm{F}$ identified the Format for the end product that the student-produced and $\mathrm{T}$ identified the Topic that would be addressed in the assignment. RAFTs were often used for the entire class, sometimes students were assigned a specific row, other times students were given the choice of a row, or when the RAFT was used for a unit all of the rows were completed by the entire class. As can be seen on the example RAFTs, some assignment rows were written for individualized student work while other rows were directed at small group completion. See Figures 5-8 for examples.

The music teacher found that over the 6-week period it was necessary to create seven different RAFTs. Her example of a RAFT for student identification of vocabulary and musical forms, with an emphasis on Rondo, is found in Figure 5. The English and History teacher collaborated on many assignments during the 6-week period. Figure 3 depicts an example of their collaborative RAFT; in English where types of writing were being reviewed (i. e., informational, persuasive, informal, and editorial) and in History where the reasons and impact of the Civil War were being studied. The English and History teachers developed and used 12 RAFTS in 6 weeks. Figure 6 is an example of one of the 8 RAFTs developed by the Physical Education teacher; this one was for a unit on teaching tennis. The mathematics teacher created 5 RAFTs across the 6 weeks. Figure 7 is a RAFT created for a review before the quiz on lines. The Science teacher created 13 RAFTs across the 6 weeks, and the RAFT example displayed in Figure 8 is for the lessons focused on organization, function, and roles of cells.

\section{Student Perceived Change}

A paired-samples t-test was conducted to determine if a statistically significant difference existed between student perceived social competence pre and post. Table 1 shows aggregated results from pre and post paired-samples t-tests performed for the students on the Social Competence Scale for Teenagers. Students in the classes where teachers used the 9-Grid and the RAFT reported their perception of social competence before the tool use compared to their perceptions after the 6 weeks. As displayed in Table 1, there are statistically significant differences, at the .05 significance level, in pretest to posttest scores for student perceived social competence skills. 
Table 1

Descriptive Statistics and t-test Results for Social Competence Scale

\begin{tabular}{|c|c|c|c|c|c|c|c|c|}
\hline \multirow[b]{2}{*}{ Outcome } & \multicolumn{2}{|c|}{ Pretest } & \multicolumn{2}{|c|}{ Posttest } & \multirow[b]{2}{*}{$\mathrm{N}$} & \multirow{2}{*}{$\begin{array}{c}\text { 95\% CI for } \\
\text { Mean } \\
\text { Difference }\end{array}$} & \multirow[b]{2}{*}{$\mathrm{t}$} & \multirow[b]{2}{*}{$\mathrm{df}$} \\
\hline & M & SD & M & SD & & & & \\
\hline $\begin{array}{l}\text { Aggregate } \\
\text { social } \\
\text { competenc } \\
\text { e } \\
\text { Scores }\end{array}$ & 11.90 & 6.64 & $\begin{array}{c}25.4 \\
5\end{array}$ & 3.86 & 20 & $-15.61,-11.49$ & $-13.78^{*}$ & 19 \\
\hline
\end{tabular}

$* \mathrm{p}<.05$.

Results showed that the overall group self-perception of their social competence increased at a statistically significant level. Results of the paired-samples t-test show that mean social competence perceptions differs before the use of the 9-grid and the RAFTs techniques $(\mathrm{M}=$ 11.90, $\mathrm{SD}=6.64)$ and after the technique use $(\mathrm{M}=25.45$, SD 3.86) at the .05 level of significance $(\underline{\mathrm{t}}=-13.78, \underline{\mathrm{df}}=19, \underline{\mathrm{p}}<.05,95 \%$ CI for mean difference -15.61 to -11.49$)$. To further identify if specific items on the Social Competence Scale indicated a change from preto-post, individual t-tests were run on the nine individual items. Five items provided the great variance. They were 1) Do you listen to other students' ideas? 2) Do you respect other points of view, even if you disagree, 3) Do you get along well with people of different races, cultures, and religions? 4) When I work in school groups, I do my fair share, and 5) I avoid making other kids look bad.

\section{Teacher Perceived Change}

Teachers reported that all students, actively participated in the lessons when using RAFTs. When the RAFT rows required group work, teachers said that the students talked and interacted with peers with whom they did not typically share information. Student weaknesses became evident when they demonstrated their learning. Teachers stated that they saw these student's needs even when the work was completed through their preferred modalities. For instance, spelling showed as a deficit skill for students while writing a script for a play when acting was their skill strength and the learning preference they desired. These insights gave the teachers the ability to add depth to the needed adaptive supports on each student's 9-Grid. Examples of added supports to the 9-Grid included the use of Word Walls for vocabulary, word banks for independent worksheets and quizzes; thus, ensuring spelling did not detour or hamper student work completion. The teachers reported that all students performed at a higher degree on assigned tasks. All teachers reported positive changes in students' social and academic behaviors. Seven of the students did not have any failing grades at the end of the grading period and were no longer considered for Tier 3 interventions in the RtI model.

\section{Research Question Results}

Research Question 1: Would students' positive social and academic work completion behaviors increase if they had more choice in how they demonstrated what they learned? According to teacher reports, the students' social and academic behaviors increased in a positive direction. Teachers said that they recognized that they provided a larger number of choices in how students demonstrated learning. They also said that they realized that giving the students more flexibility in how to show their learning fit better with how the students viewed their understanding.

Research Questions 2: Would students' positive social and academic work completion behaviors increase if the teachers supported work completion with a variation of input? A 
correlation was found when the more variation a teacher reported using for instructional modalities, then the amount of student work completed increased. The teachers who said they had difficulty articulating how they would divert from their standard input of instruction saw less positive gain by students in academic behaviors and work completion.

Research Questions 3: Would students' social and academic misbehaviors decrease if the teachers used instructional methods that allowed more student choice, interaction, and/or physical movement than they currently allowed? Teachers reported the use of the 9-grid allowed them to examine how they provided initial instruction and to explore ways to expand the modalities they used and choices they were able to provide. All teachers reported they increased their use of group work creating more student interactions. They reported that all students increased in positive social behaviors during assignments when teachers used the RAFT and the 9-Grid.

Research Question 4: Would students' social and academic misbehaviors decrease if assignments were integrated with items of interest to their daily lives? Both teachers and students were asked how they viewed social and academic behaviors when assignments included students' indicated interests. Teachers said the target students participated at least twice as much as they had previously, that the academic work included a greater degree of care and a decrease in the number of misspellings and grammatical errors on written work and syntax during verbal presentations. Students reported that they enjoyed the assignments more because they felt capable of doing what was asked of them from the start. They said that they felt that they did not have to work as hard to integrate their knowledge into the assignment.

\section{CONCLUSION}

Teachers can use students' strengths and interests to promote attempting difficult tasks through various modalities of teacher input and the student learning output. Adaptations can support students in the development of attempting alternative approaches to difficult or new learning tasks. Teachers can understand the diverse nature of the classroom of students while simultaneously expanding their abilities through the incorporation of student interest and preferences. Students' new learning can help eliminate avoidance of perceived difficult assignments and disruptive behaviors. This study confirmed, previous findings by Kauffman (2010) and Witt, VanDerHeyden, and Gibertson (2004), that when students can engage in, and function with competence using curriculum materials, not only do their misbehaviors occur less often, but their academic participation and grades increased.

In this study, the use of the 9-grid to identify specific adaptations for student's social and academic need in combination with a RAFT that integrated student interest and preferences led to greater assignment completion and positive student participation in classes. Transitioning students back into content areas from which they have been or are being considered for removal due to academic or social behavioral reasons is the goal; whether a tier program for interventions is used or another model. Providing teachers with instructional interventions to identify and address the behavioral and academic needs of students while maintaining standards and levels of competence enables them to respond more effectively.

\section{References}

Arcia, E. (2006). Achievement and enrollment status of suspended students: Outcomes in a large, multicultural school district. Education and Urban Society, 38, pp. 359-369.

Butler, H., Bond, L., Drew, S., Krelle, A., \& Seal, I. (2005). Doing it differently: Improving young people's engagement with school. Brotherhood of St Laurence, Melbourne, Australia.

Child Trends (2003). Indicauchstors of positive development conference summary. Washington: Author. 
DeSchenes, C. Ebeling, D. \& Sprague, J. (1994). Adapting curriculum \& instruction in inclusive classrooms: A teacher's desk reference. ISDDCSCI Publication.

DeWitt, P. (2016). Do teachers need Response to Intervention? Retrieved from edweek.org/edweek/finding_common_ground 2016/03/do_teachers_need_response_to_intervention.html Freitag, M. (1997). Reading and writing in the mathematics classroom. The Mathematics Educator, 8(1), 16-21. Grant, S.G. \& Gradwell, J.M. Eds. (2010). Teaching history with big ideas: Cases of ambitious teachers. Rowman \& Littlefield Education: Lanham, MD.

Holston, V. \& Santa, C. (1985). RAFT: A method of writing across the curriculum that works. Journal of Reading, 28(5), 456-457.

Individuals with Disabilities Education Improvement Act of 2004 (2004). 34 C.F.R. et seq.

Johns, B.H. (2015). 401 practical adaptations for every classroom. Skyhorse Publishing: New York, NY.

Kauffman, J.M. (2010). Commentary: Current status of the field and future directions. Behavioral Disorders, 180184.

Lenski, S.D., \& Lewis, J. (2008). Reading Success for Struggling Adolescent Learners. Guilford Press: New York, NY.

Levendoski, L.S., \& Cartledge, G. (2000). Self-monitoring for elementary school children with serious emotional disturbances: Classroom applications for increased academic responding. Behavioral Disorders, 25, $211-224$.

National Center for Learning Disabilities (2018). The use of RTI to identify students with Learning Disabilities: A review of the research. Retrieved from www.rtinetwork.org.

National Center on Response to Intervention (2017). Essential components of RTI: A closer look at response to intervention. Retrieved from http//www.rti4success.org

O’Shaughnessy, T.E., Lane, K.L., Gresham, F.M., \& Beebe-Frankenberger, M.E. (2002). Students with or at risk for learning and emotional-behavioral difficulties: An integrated system of prevention and intervention. In K.L. Lane, F.M. Gresham, \& T.E. O'Shaughnessy (Eds.), Interventions for children with or at risk for emotional and behavioral disorders (pp. 3-17). Boston: Allyn and Bacon.

Parilasanti, N.M.E. (2014). The effect of RAFT strategy and anxiety upon writing competency of the seventh grade students of SMP Negeri 3 Mengwi in academic year 2013/2014. Denpasar: Universitas Pendidikan Ganesha

Price, K.M., \& Nelson, K.L. (2014). Planning effective instruction: Diversity responsive teaching (5 ${ }^{\text {th }}$ ed.). Belmont, California: Thompson.

Reid, R., Gonzalez, J.E., Nordness, P.D., Trout, A., \& Epstein, M.H. (2004). A meta-analysis of the academic status of students with emotional/behavioral disturbance. The Journal of Special Education, 38(3), 130-143.

Sabornie, E. J., Cullinan, D., Osborne, S.S., \& Brock, L.B. (2005). Intellectual, academic, and behavioral functioning of students with high-incidence disabilities: A cross-categorical meta-analysis. Exceptional Children, 72(1), 47-63.

Schinck-Mikel, A. \& Pugalee, D. (2014). Writing in middle grades mathematics. Retrieved from www.amle.org

Skiba, R.J., \& Rausch, M.K. (2006). Zero tolerance, suspension, and expulsion: Questions of equity and effectiveness C.M. Evertson, C.S. Weinstein (Eds.), Handbook of classroom management: Research, practice, and contemporary issues, Lawrence Erlbaum Associates, Mahwah, New Jersey, pp. 1063-1089

Sprenger, M.B. (2008). Differentiation through learning styles and memory. Corwin Press: Thousand Oaks, CA Tomlinson, C.A. (2014). Differentiated classroom: Responding to the needs of all learners. ASCD.

Vellutino, F.R., Scanlon, D.M., Small, S., \& Fanuele, D.P. (2006). Response to intervention as a vehicle for distinguishing between children with and without reading disabilities: Evidence for the role of kindergarten and first-grade intervention. Journal of Learning Disabilities, 39(2), 157-169.

Williamson, M.R., \& Watson, R.L. (2006). Learning styles research: Understanding how teaching should be impacted by the way learners learn. Christian Education Journal, 3(1), 27-42.

Witt, J.C., VanDerHeyden, A.M., \& Gibertson, D. (2004). Instruction and classroom management: Prevention and intervention research. In R.B. Rutherford, M.M. Quinn, \& S. R. Mathur (Eds.), Handbook of research in emotional and behavioral disorders. New York: Guildford Press. 
Figure 5. Example of RAFT for Vocabulary and Musical Forms Identification in Music

\begin{tabular}{|l|l|l|l|}
\hline \multicolumn{1}{|c|}{ Role } & \multicolumn{1}{|c|}{ Audience } & \multicolumn{1}{c|}{ Format } & \multicolumn{1}{c|}{ Topic } \\
\hline Cross Country Skier & $\begin{array}{l}\text { The Forest and } \\
\text { Woodland Creatures }\end{array}$ & $\begin{array}{l}\text { Performance on the } \\
\text { xylophone }\end{array}$ & $\begin{array}{l}\text { Skiing downhill } \\
\text { Rondo Style -- Form } \\
\text { "A" }\end{array}$ \\
\hline Dancer & $\begin{array}{l}\text { People in Performance } \\
\text { Hall }\end{array}$ & $\begin{array}{l}\text { Performance of } \\
\text { repetition --- Dance to } \\
\text { the music when you } \\
\text { hear B, C, D section of } \\
\text { Rondo }\end{array}$ & $\begin{array}{l}\text { Happy Feet Copy } \\
\text { Rondo }\end{array}$ \\
\hline $\begin{array}{l}\text { Ankeruhr Clock in } \\
\text { Vienna }\end{array}$ & $\begin{array}{l}\text { People in the Streets } \\
\text { of Vienna }\end{array}$ & $\begin{array}{l}\text { Imitation of the clock } \\
\text { with the bells }\end{array}$ & $\begin{array}{l}\text { Can You Rondo? } \\
\text { (Identify and } \\
\text { Imitate) }\end{array}$ \\
\hline Singer & Folks Song audience & $\begin{array}{l}\text { Teach a Rondo Folk } \\
\text { Song of your choice to } \\
\text { audience }\end{array}$ & $\begin{array}{l}\text { Sing songs in Rondo } \\
\text { Form }\end{array}$ \\
\hline
\end{tabular}

Figure 6. Example of RAFT for Tennis Unit.

\begin{tabular}{|l|l|l|l|}
\hline \multicolumn{1}{|c|}{ Role } & \multicolumn{1}{c|}{ Audience } & \multicolumn{1}{c|}{ Format } & \multicolumn{1}{c|}{ Topic } \\
\hline $\begin{array}{l}\text { Exercise Coach } \\
\text { Leading Proper } \\
\text { Warm-Up Stretching } \\
\text { Routine }\end{array}$ & Class & Lead a Routine & $\begin{array}{l}\text { It More Than Going } \\
\text { Through Motions }\end{array}$ \\
\hline TV Announcer & $\begin{array}{l}\text { Audience Watching } \\
\text { Match }\end{array}$ & $\begin{array}{l}\text { Video Visual Slow-Moe } \\
\text { Presentation of } \\
\text { Backhand }\end{array}$ & $\begin{array}{l}\text { Don't Backhand Me! } \\
\text { Let's See It Again }\end{array}$ \\
\hline Pencil & Score Sheet & Cartoon & $\begin{array}{l}\text { You Can't Keep Score } \\
\text { Without me - Let Me } \\
\text { Show You How it is } \\
\text { Done }\end{array}$ \\
\hline $\begin{array}{l}\text { Ball Teaching } \\
\text { Forehand Technique }\end{array}$ & Racket & Poster & Show me the Way \\
\hline
\end{tabular}

Figure 7. Example RAFT for Mathematic Quiz Review

\begin{tabular}{|l|l|l|l|}
\hline \multicolumn{1}{|c|}{ Role } & \multicolumn{1}{c|}{ Audience } & \multicolumn{1}{c|}{ Format } & \multicolumn{1}{c|}{ Topic } \\
\hline Police Scanner & General Public & Police Report & $\begin{array}{l}\text { The Nefarious Y- } \\
\text { Intercept: How Did You } \\
\text { Track Him Down? }\end{array}$ \\
\hline The Chief & The Gumshoes & $\begin{array}{l}\text { Picture for Where in } \\
\text { the World is Carmen } \\
\text { San Diego? }\end{array}$ & $\begin{array}{l}\text { Quadrants of the } \\
\text { Cartesian Plane: Will } \\
\text { They Help Us Find Her? }\end{array}$ \\
\hline Line Segment & $\begin{array}{l}\text { Other Line } \\
\text { Segments, Lines, } \\
\text { and Rays }\end{array}$ & Journal Entry & Why Am I a Dead End? \\
\hline Straight Line & Other Lines & $\begin{array}{l}\text { Full Page Personal } \\
\text { Ad }\end{array}$ & Can We Be Parallel? \\
\hline
\end{tabular}


Figure 8. Example RAFT for Science

\begin{tabular}{|l|l|l|l|}
\hline \multicolumn{1}{|c|}{ Role } & \multicolumn{1}{|c|}{ Audience } & \multicolumn{1}{c|}{ Format } & \multicolumn{1}{c|}{ Topic } \\
\hline Cell organelle/part & $\begin{array}{l}\text { Future Cancer } \\
\text { Researchers } \\
\text { (Cytologists) }\end{array}$ & $\begin{array}{l}\text { Owner's Manual for } \\
\text { Cell Organization }\end{array}$ & $\begin{array}{l}\text { Work with Me } \\
\text { People! }\end{array}$ \\
\hline $\begin{array}{l}\text { Active/Passive } \\
\text { Transport Mechanism }\end{array}$ & $\begin{array}{l}4^{\text {th }} \text { grade class } \\
\text { Photosynthesis \& }\end{array}$ & $\begin{array}{l}\text { Field Trip Travel Guide } \\
\text { for Cell Homeostasis }\end{array}$ & $\begin{array}{l}\text { Going With (or in } \\
\text { this case) Against } \\
\text { the Flow }\end{array}$ \\
\hline Mespiration & Teenagers & $\begin{array}{l}\text { Rock and Roll Lyrics } \\
\text { for Cell Energetics }\end{array}$ & $\begin{array}{l}\text { We Need Each } \\
\text { Other }\end{array}$ \\
\hline
\end{tabular}

